\title{
TMP 廃蒸気からの熱回収
}

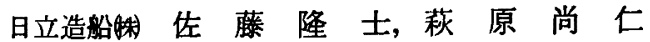 \\ Heat Recovery from TMP Waste Steam}

\author{
Takashi Sato and Shoji Hagiwara \\ Hitachi Zosen Corp.
}

In this paper, a method of heat recovery to produce clean steam used as a general heat source from TMP waste steam is described and assessed whether investment in heat recovery system is feasible.

Keywords: TMP, Heat recovery, Refiner, Waste steam, Evaporator, Heat pump, Fouling coefficient, Heat transfer coefficient

\section{1. まえがき}

日立造船は米国バウア社との技術提搭によるダブル ディスクリファイナー (DDR) の優れた機能を取入れ， 数多くの RGP 及び TMP プラントを納入してきた。 これらの経験から痛感することは, リファイナーでの 発生蒸気の有効利用とリファイニング動力低滅のむず かしさである。

メカニカルパルプの中で TMP は強度特性に優れ, 不透明度も高いことから新聞用紙の軽量化に適したパ ルプとして增産されてきた。しかし，電力消费量が多 いことからエネルギー低減が最大の課題となっている。 現在，TMP 製造工場で取組んでいるエネルギー低 减の方法には次のようなものがある。

(1) 発生蒸気のもつエネルギーの回収

（2）機械的または化学薬品前処理によるリファイナ 一動力の低減

(3) コンピューターなどの活用による電力変動の減 少にともなら無効電力の減少

これらの方法のらち，(1)項の発生蒸気からの熱回収 は最も具体的に実行しやすい対策である。

TMP プラントの電力はリファイナーで約 $90 \%$ が 消費される。そのエネルギーの $95 \%$ 以上が蒸気に変 換される。この発生蒸気のらち約 15〜20\%はスチー ミング工程でチップの加熱に消費され，残りの余剩蒸 気（廃蒸気と呼ぶ）より熱回収が計られる。
標準的 TMP プラントは加圧形と大気圧形を組合せ た 2 段リファイニンクシステムである。廃蒸気も 100 ${ }^{\circ} \mathrm{C}$ 以下で，これを回収利用するとき得られるエネル ギー形態は温水などに限定され，従来は大部分がその まま大気へ放出されていた。これらの廃蒸気量はパル ブ 1t つくるのに 2.0 2.5t にも達する。一方, TMP ブラントの省エネ化が本格的に検討され始めた 1970 年後半からリフォイニング工程を加圧クローズド化し， 高圧の廃蒸気を取出す試みが北欧，カナダで始められ， 1980 年代には，1 次・2 次リファイニングとも加圧 下で行う 2 段加圧リファイニングシステム（タンデム システム）も開発された。これらの高圧廃蒸気を利用 してェパポレーター（リボイラーとる呼ばれる）でク リーン蒸気が生成され，TMP プラント内に限らず幅 広いエネルギー源として利用されるようになってきた。

本文では TMP プラントの廃蒸気を熱源としてクリ ーン蒸気を発生させ，これをプロセス蒸気に置き換え る省エネルギー化について当社の実績を踏まえ紹介す る。

\section{TMP プロセスと発生菜匃}

\subsection{TMP プロセス}

TMP プラントの機能的流れは各プラントメーカー とも基本的にほぼ同じである。一方，椣成機器はパル プ品筫や熱回収などの面から各社それぞれ性能・棈造 に工夫をこらしている。現在，スチーミング工程での 
チップ加熱用蒸気はリファイナー発生蒸気にて全量供 給されメークアップ蒸気は不要となってきた。当社 の TMP プロセスでは熱回収や高濃度りファイニング での安定化を計るため，加圧形 DDR には主軸にリボ ンスクリューを取付けたコアキシャルフィーダーを， また大気圧形 DDR には図 1 に示したシングルリボン スクリューとコアキシャルフィーダーを組み合わせた トップワインダーフィーダーを採用している。

TMP プロセスはリフォイニングの方法により次の 3つに大別される。

(1) 加圧形 1 段リフォイニングシステム

（2）（加匤形十大気圧形） 2 段リフォイニングシステ

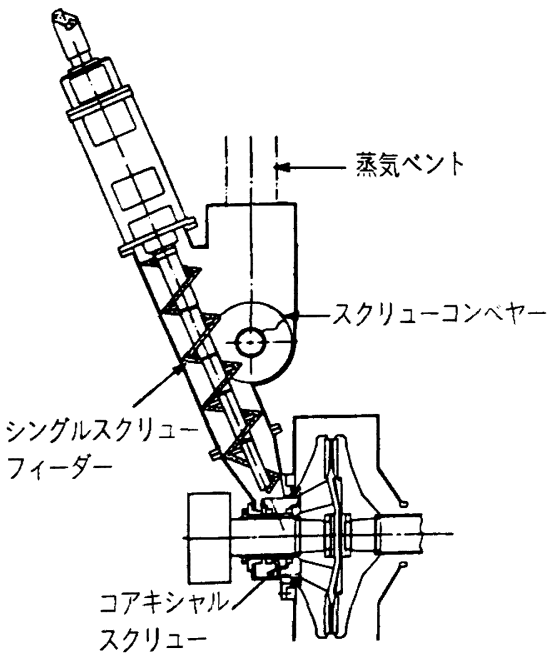

図1トップワインダーフィーダー
$\Delta$

（3）（加殴形＋加圧形） 2 段加任リファイニングシス テム

(1)のシステムは原料の良い北欧で採用されているシ ステムであるが日本での実績はない。

(2)のシステムは従来から標準的 TMP プロセスで採 用されているシステムである。この標準的 TMP プロ セスの5ち，1次リファイナーからブローされた原料 を蒸気から分離するために使われるサイクロンを大気 圧形から加圧形に変更し，高圧蒸気を取出してプロセ ス蒸気に置き換えることにより熱回収を計る工場が多 くなってきた。バウア社は本方式による TMP 廃蒸気 からクリーン蒸気を発生させる熱回収装置の害績を 7 件持って扣り, 当社でも 1984 年に日本で初めて大王 製紙三島工場に納入した。

(3)のシステムは 1 次扰よび 2 次のメインリファイニ ングを加圧下で行い，熱回収を一層徽底させたシステ ムである。ハウウア社は本システムに対して下記 7 社の 実績を持っている。

Enso-Gutzeit, Summa 工場（操業中）

Enso-Gutzeit, Kotka 工場（操業中）

Bowater Newfoundland, Cornerbrook 工場 (操業中)

Bowater Southern, Calhoun 工場（操業中）

F. F. Soucy, Quebec 工場（操業中）

Bowater Carolina, Catawba 工場

（1986 年操業予定）

Kruger, Bromptonville 工場

（1986 年操業予定）

数年前までは $2 \sim 3 \mathrm{~kg} / \mathrm{cm}^{2} \mathrm{G}$ のクリーン蒸気を発

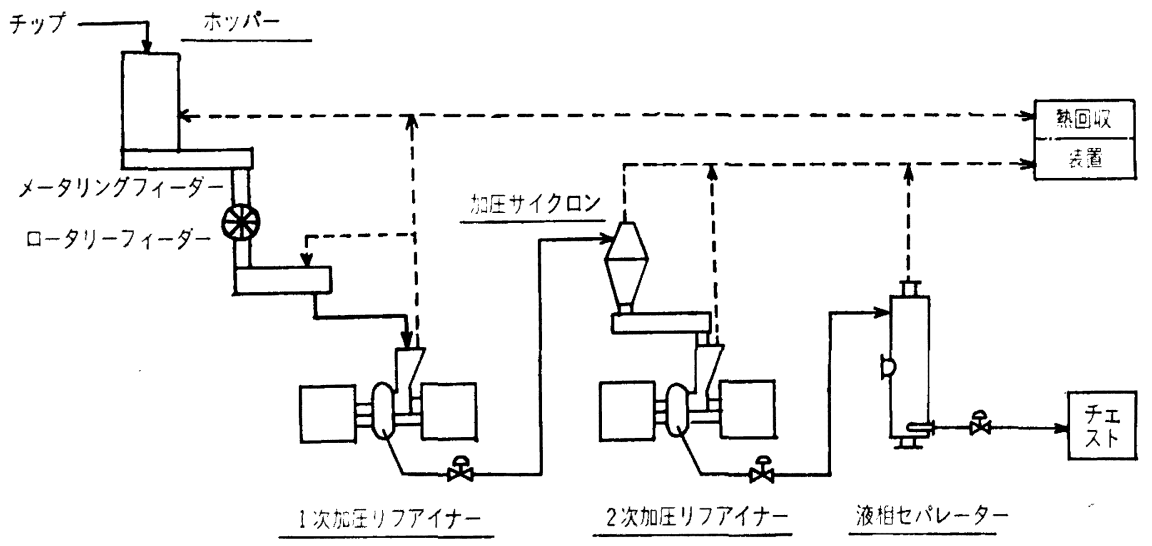

图 22 段加圧リファイニングシステム 
生させる熱回收装置が多かったが，1985 年以降は 2 段加圧りファイニングシステムからの廃蒸気により, $3.5 \mathrm{~kg} / \mathrm{cm}^{2} \mathrm{G}$ 程度のクリーン蒸気を発生させ, このク リーン蒸気をそのまま抄紙機のドライヤーで使用する 方式が実施されてきた。

図 2 に 2 段加圧りファイニングシステムのフローを 示した。

\section{2 廃蒸父の発生旦と性状}

TMP プロセスの熱バランスは系内に入る希釈水の 温度, 回収水の温度, さらにリフォイナーの安定運転 に必要なリファイナ一動力負荷率およびプロセス内の 圧力ハラランスなどを教虑して決定される。

標準的 TMP ブロセスで発生する1次りファイニン グ後の廃蒸気 (約 $100^{\circ} \mathrm{C}$ ) は, リファイナー動力を 42 $\mathrm{kw} \cdot \mathrm{d} / \mathrm{ADt}$ 加えたとき，約 $0.8 \mathrm{t} / \mathrm{ADt}$ (ハルブ) 発生す る。 $35 \mathrm{kw} \cdot \mathrm{d} / \mathrm{ADt}$ かけた 2 次リフォイニング後の廃 蒸気 $\left(90 \sim 100^{\circ} \mathrm{C}\right)$ は約 $0.8 \sim 0.9 \mathrm{t} / \mathrm{ADt}$ (ハルク)である。 これらの值はリフォイナーのブラグワイパー水やプロ セス希釈水の大部分に常温の清水を使用した場合であ

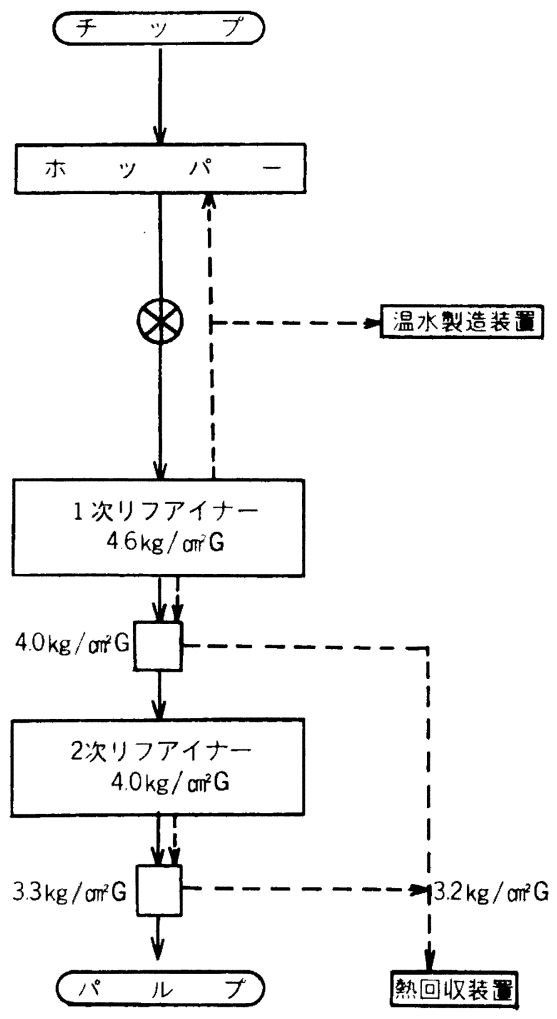

图３2段加王リフォイニングシステム 仼力ハランンス
る。清水の代わりに 70〜 $80^{\circ} \mathrm{C}$ のクリア白水を使用す れば，同じッファイナー動力で廃蒸気量はさらに増え， 1 次リファイニング後で約 $1 \mathrm{t} / \mathrm{ADt}$ (ハルブ), 2 次り ファイニング後で的 $1.1 \mathrm{t} / \mathrm{ADt}$ (ハルブ)となる。

2 段加圧リファイニングシステムで重要なことは, 1 次・2次リファイニングを安定化させるための圧力 バランスである。図3に標準的圧力ハラランスを示した。 この圧力バランスから 2 段加圧リファイニングシステ ム全体のエネルギーバランスをとると図4のよらにな る。本図をみると，2次りファイナーから発生する蒸 気エネルギーは1 次リファイナーからの蒸気エネルギ 一の約 1.3 倍あり, 両者合わせると多大な高圧廃蒸気 エネルギーとなる。これらの高圧廃蒸気からエネルギ 一回収を行らことに 2 段加任リファイニングのメリッ トがあると言える。なお， バウア社では 2 段加圧りフ フイニンクシステムにはスチーミング装置を設けず, このシステムから標準的 TMP プロセスと同等のパル プ品質を得ている。

TMP システムから発生する廃蒸気は木材中の揮発 性有機物やェアを含んでいる。廃蒸気からの熱回収で はこれらの不純物の影繁を考虑して計画する。1次り ファイニングからの廃蒸気中にはチップに随伴して混 入するエアが約 $0.1 〜 0.4$ 重量\%，揮発性有機物（ター ペンチン, テルペン、エタノール, 蟻酸, 酢酸など) が約 $0.3 \sim 3$ 重量\%含まれる。揮発性有機物は水蒸気 の潜熱を椤ったたけではほとんど凝縮せず，不凝維ガ スとしての挙動を示す。これらのらち特に蟻酸と酢酸 は酸性が強く, 廃蒸気凝樎液の $\mathrm{pH}$ は $2.5 〜 4$ 位となる。 また，通常廃蒸気はサイクロンセパレーターでパルプ と分離されるため微細なフォイバーが含まれる。この 量はサイクロンセパレーターでのファイバー捕集率拉 よび廃蒸気圧力の変動によって大きく変り, 特に, プ ラントのスタートアップ時にファイバーが廃蒸気側に 流れやすいため注意が必要である。2次リファイニン グからの廃蒸気の性質は 1 次リフォイニングに比べ不 純物の含有量が相当少なく, 廃蒸気凝縮液の $\mathrm{pH}$ もそ れはど低くはならない。

\section{3 庭熱回収方法}

TMP 製造工場では何らかの形で熱回収設備を導入 している。廃蒸気からの熱回収としては, 一般に表 1 に示す方法がある。廃熱回収を行らとさは, 前記の廃 蒸弎に含まれる各種不純物による機器への影留および その処理方法を十分考虫しておく必要がある。

ファイパー :

熱交换器の污れ，廃蒸気ラインのつまり，排気 ファンヘの付着による振動の発生など起こす。 


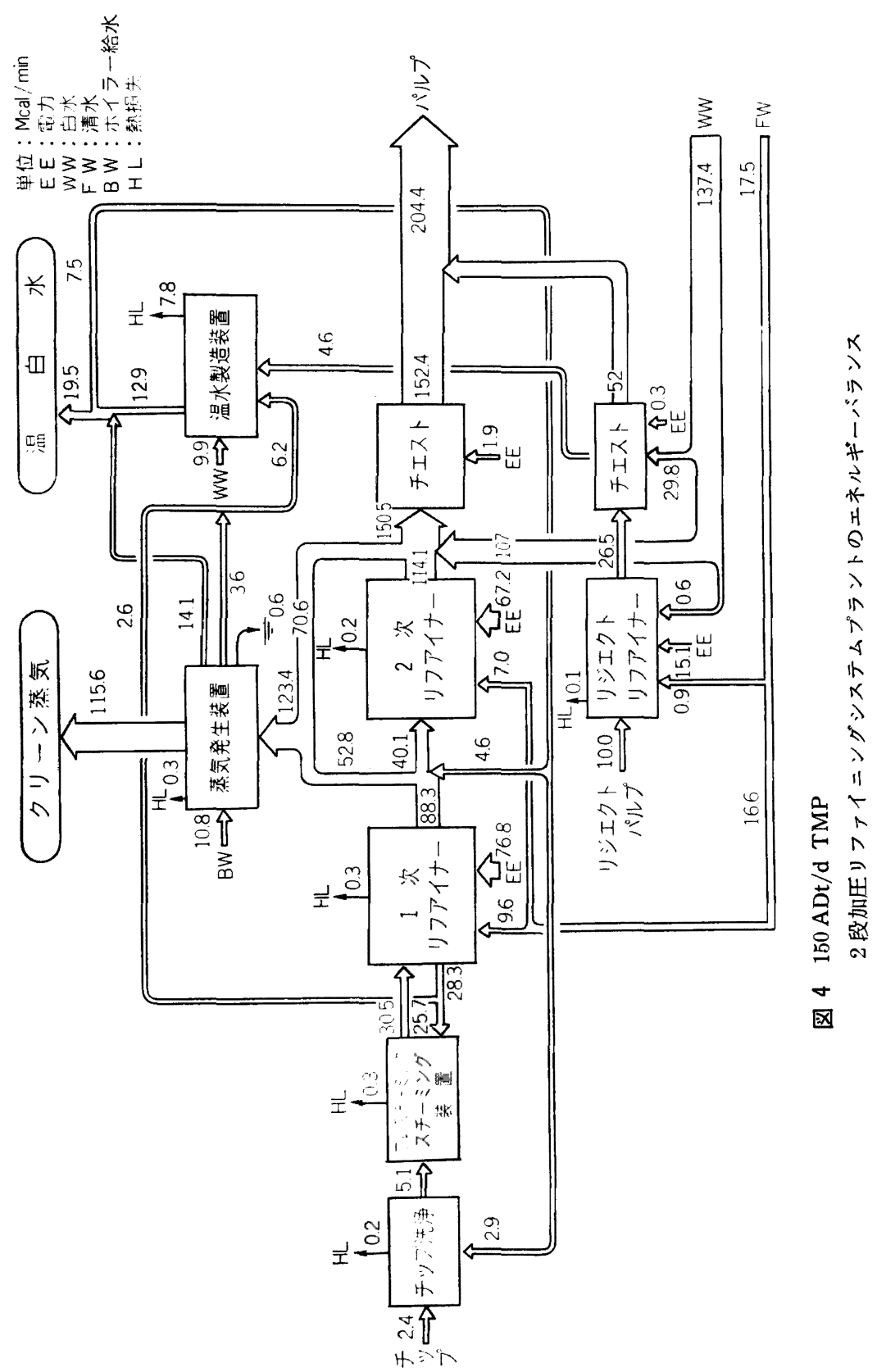

ペンチュリースクラパ，温水シャワー，サイ クロンセパレーター,エリミネーターなどで除 去する。

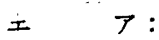

熱交换が阻害される。

2 段加压リファイニングシステムの採用，適切
なエア抜きなどにより影響を除く。 有 機酸:

金属材料の腐食を起こす。

廃蒸気と接する部分の材塤はSUS 304，また廃 蒸気凝縮液と接する熱交換器や配管の材質は SUS 316 あるいは SUS $316 \mathrm{~L}$ 相当を使用する。 


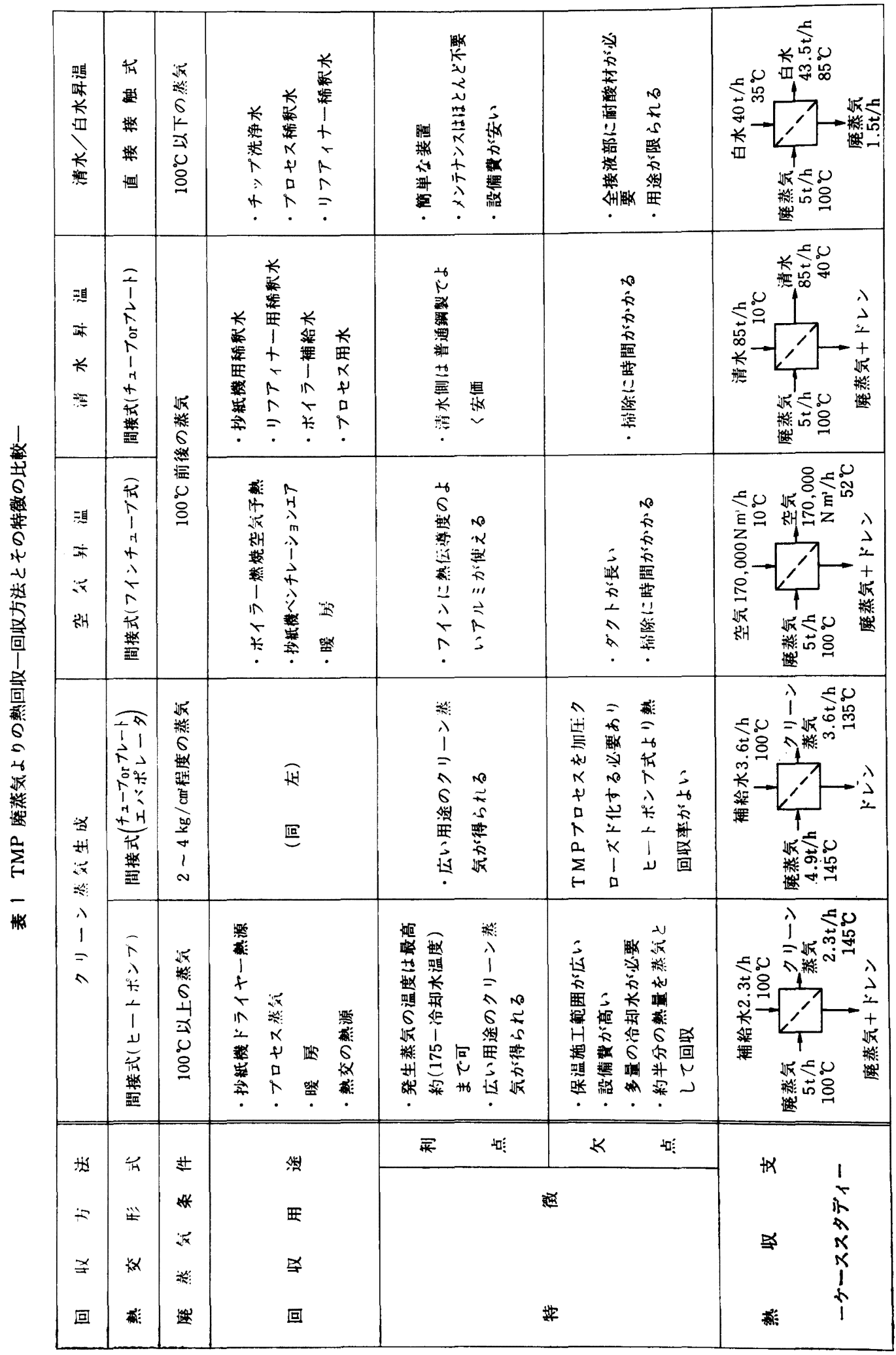


ここでは廃熱回収方法として, 最近操業実績が増加 してきた廃蒸気を利用したクリーン蒸気生成の方法, すなわち，ヒートポンプ方式とエパポレーター方式に ついて,その特䑾を述べる。

1）吸収ヒートポンプ方式

吸収ヒートポンブは臭化リチウム $(\mathrm{LiBr})$ 水溶液と 冷媒（水）の飽和蒸気王の違いを利用して，廃蒸気以 上の王力を持つ蒸気を取出すことがでさるものである。 装置の基本構成は廃蒸気の持つ熱で令媒を蒸発させる 「蒸発器」, この洽媒蒸気を $\mathrm{LiBr}$ 水溶液へ吸収させ, 廃蒸気以上の王力を持つ蒸気を取出す「吸収器」, 濃 度の薄くなった $\mathrm{LiBr}$ 水溶液を廃蒸気で濃 粨させる 「再生器」およびこの再生器で発生した冾媒蒸気を冷 却水で凝樎させる「凝縮器」の 4 種類の主要熱交換器 から成る。基本フローを図 5 に記載した。

TMP プラントの廃蒸気に適用されるのは第 2 種ヒ ートポンプであり，取出せるクリーン蒸気の温度は $150^{\circ} \mathrm{C}$ 位まで可能である。一般にクリーン蒸気温度の 概略值は次式で与えられる。

$$
\begin{aligned}
\mathrm{T}_{\mathrm{o}}= & \mathrm{T}_{\mathrm{i}}+\left(\mathrm{T}_{\mathrm{i}}-\mathrm{T}_{\mathrm{c}}-25\right) \\
& \mathrm{T}_{\mathrm{o}}: \text { クリーン蒸気温度 }{ }^{\circ} \mathrm{C} \\
& \mathrm{T}_{\mathrm{i}}: \text { 廃蒸気温度 }{ }^{\circ} \mathrm{C} \\
& \mathrm{T}_{\mathrm{c}}: \text { 冷却水温度 }{ }^{\circ} \mathrm{C}
\end{aligned}
$$

$\mathrm{T}_{\mathrm{o}}$ - $\mathrm{T}_{\mathrm{i}}$ を通常，昇温幅と称し上式からわかるよう に廃蒸気温度と冷却水温度により一義的に決る。廃蒸 気を高温で取出せれば，それに応した高温クリーン蒸 気を発生させることがでさる。一定温度のクリーン蒸 気を発生させる場合には，廃蒸気温度が高いほど，す なわち, 昇温幅が小さいほど吸収ヒートポンプの設備 費は割安となる。

熱回収量はおよそ廃蒸気保有熱量の $50 \%$ であり， 残りの熱量は冾却水側へ流れる。したがって，30〜35 ${ }^{\circ} \mathrm{C}$ の多量の命却水が有効に利用できる場合は $100 \%$ の熱回収が可能となる。海水が冷却水として使えると

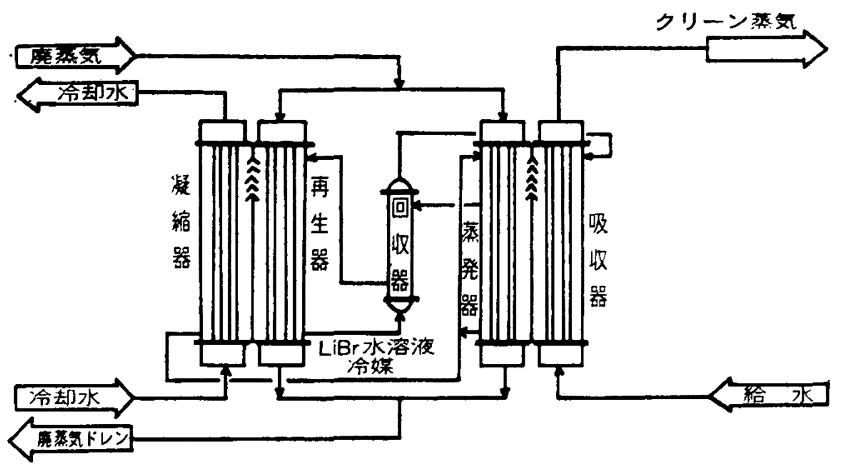

图 5 吸収ヒートポンプ式クリーン蒸気発生装置
ころでも吸収ヒートポンプが有効な熱回収装置となる。

2) エバポレーター方式

エパポレーター式クリーン蒸気発生装置の特徵は高 い廃蒸気圧力から，一定の温度差でクリーン蒸気を取 出す, 水蒸気凝縮 - 水蒸気蒸発の熱交換を行ら点にあ る。リフォイニングプロセスから，このような代力を 持つ廃蒸気を安定して取出せれば単純な熱交換器でよ い。

当社の標準的熱回収フローを図 6に示した。

当社は多管式およびプレート式エパポレーターを製 作でき，垂直多管式エパポレーターの第 1 号機は 1984 年大王製紙の TMP ラインに組込まれ, 現在順調に稼 動中である。

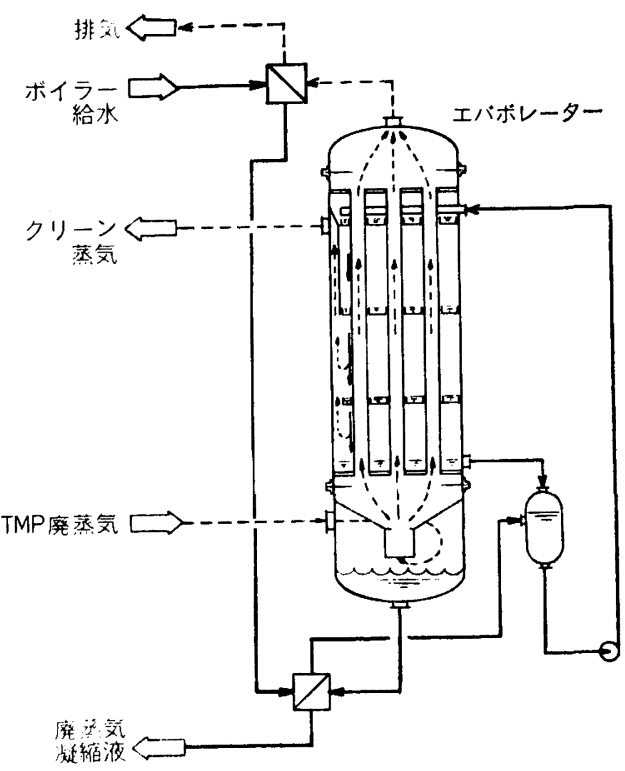

図 6 エパポレーター式クリーン蒸気発生装置 エパポレーターは管内あるいはエレメ ント外が廃蒸気の凝縮側で，廃蒸気を下 部より上部へ垂直に流す立形とすること により，廃蒸気中のフォイバーやピッチ などを廃蒸気凝縮液にて自己洗浄する効 果を持たせている。また，このタイプは 機械洗浄がしやすい。管外あるいはエレ メント内は蒸発側で，䔦い流下液膜を形 成し蒸発効果を高めている。管外の流下 液膜形成は当社の立形吸収ヒートポンプ の技術を応用し，上部に設けた 2 段の特 殊分配板から各管に均一分流させ，さら 
に数段の下部分配板で薄膜を確実に形成させることを 特徴としている。

エパポレーターの伝熱面積や平均温度差は廃蒸気の 量と性状および発生クリーン蒸気量から決まる。

廃蒸気とクリーン蒸気との温度差は, クリーン蒸気 王力と伝熱面栍とのバランスから, 当社は $5^{\circ} \mathrm{C}$ 前後(圧 力差で約 $0.5 \mathrm{~kg} / \mathrm{cm}^{2}$ ) を設計べースとしている。

水蒸気の凝縮と蒸発との熱交換におけりる総括伝熱保 数は，水質管理が良ければ污れ係数が小さくとれるた め，ほぽ各境膜伝熱係数で决まる。水蒸気中に不凝縮 ガスが混入されると我蒸気の分圧が下がって，混合が スの温度が低下するとともに，凝縮側の境膜伝熱係数 は減少する。図7に不凝縮ガスを含む水蒸父凝樎にお。 ける境膜伝熱係数の傾向を示した。したがって，不凝 縮ガスによる层熱係数の低下を防止するためにエパポ レーターから廃蒸気の一部（通常，入口廃蒸気の 2 10\%) を逃がしている。

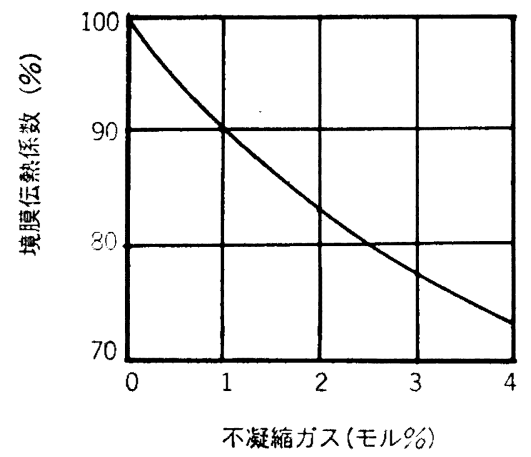

図 7 不凝縮ガス量と境膜层熱係数

伝熱面の污れはクリーン蒸気発生量を減少させるの で，当社は廃蒸気側の污れ防止として，(1)ファイハー はエパポレーター下部に設けたサイクロン効果による 分離と伝熱面での自己洗浄で除去されるが，必要なら ペソチュリースクラバーをエパポレーター入口に設け る，(2)タールやピッチ分は定期的に $\mathrm{NaOH}$ 水溶液に より洗浄する，といら方法をとっている。蒸発水とし てはボイラー給水やプロセス蒸気ドレンなどを用いる ため，クリーン蒸気側の污れは廃蒸気側ほど短期間で ひどくはならない。蒸発側伝熱面の污れは化学洗浄す る以外にないが，蒋品に強酸を使うことが多く，腐食 の点で好ましくない。このため，ブローダウンが污れ 防止に有効な手段となるが絶対的なるのではなく，清 缺剂の使用と合わせて実施する方法が確実である。

\section{4 低圧蒸気の界圧}

ヒートポンプやエバポレーターで発生した蒸気は通 常 $2 \sim 3 \mathrm{~kg} / \mathrm{cm}^{2} \mathrm{G}$ である。このため, プロセス蒸気 や抄紙機ドライヤー熱源として単純に置き換えられな いことがある。このような場合に，サーモコンプレッ サーやメカニカルコンプレッサーで所要圧力まで界王 してから供給する方法がある。サーモコンプレッサー は高圧の駆動蒸気で低王蒸気を吸込み, 混合後, 中圧 蒸気とするスチームエジェクターである。駆動蒸気は $5 \sim 15 \mathrm{~kg} / \mathrm{cm}^{2} \mathrm{G}$ 程度のむのが使用される。図 8 に駆 動蒸気圧力 $10 \mathrm{~kg} / \mathrm{cm}^{2} \mathrm{G}$ に打ける吸入比（駆動蒸気 量/吸入蒸気量）と吐出圧力の関係を示した。

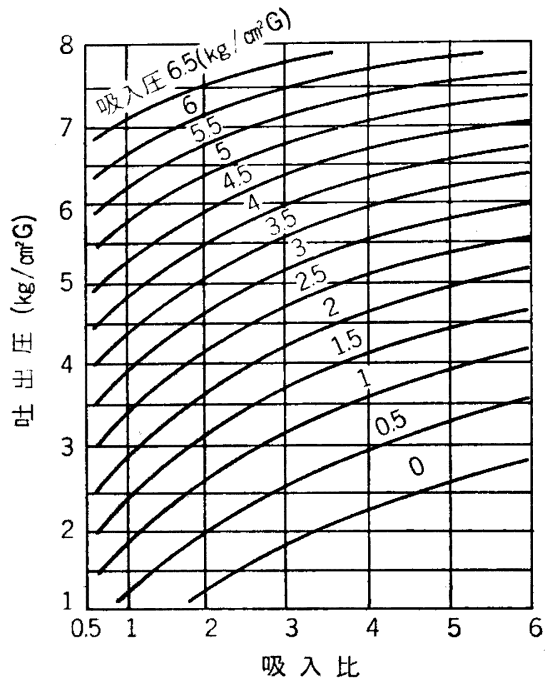

图 8 サーモコンプレッサー吸入比曲線 (駆動蒸気圧 $10 \mathrm{~kg} / \mathrm{cm}^{2} \mathrm{G}$ )

\section{3. 释済性検討}

ここではエパポレーター方式で発生させたクリーン 蒸気が単純にプロセス蒸気に罱き換わるとして経済性 を検討する。 $150 \mathrm{ADt} / \mathrm{d}$ の TMP プロセスより廃熱 回収装嗄へ $3.5 \mathrm{~kg} / \mathrm{cm}^{2} \mathrm{G}$ の廃蒸気を供給し，約 $3 \mathrm{~kg}$ $/ \mathrm{cm}^{2} \mathrm{G}$ のクリーン蒸気を得るため，(1) 1 次リフォイ ニング後までを加圧システムとした場合，(2) 2 段加压 リファイニングシステムとした場合について考える。 図 9 に蒸気単価に対するエハホポレーター設備の設備費 哄却年数の関係を示した。なお，設䚚費償却年数は次 武で算出している。

$$
\begin{aligned}
& \text { 設 偖费 } \\
& \text { 供却年数 }
\end{aligned}=\frac{\text { 設 }}{(\text { 備 费 }}
$$




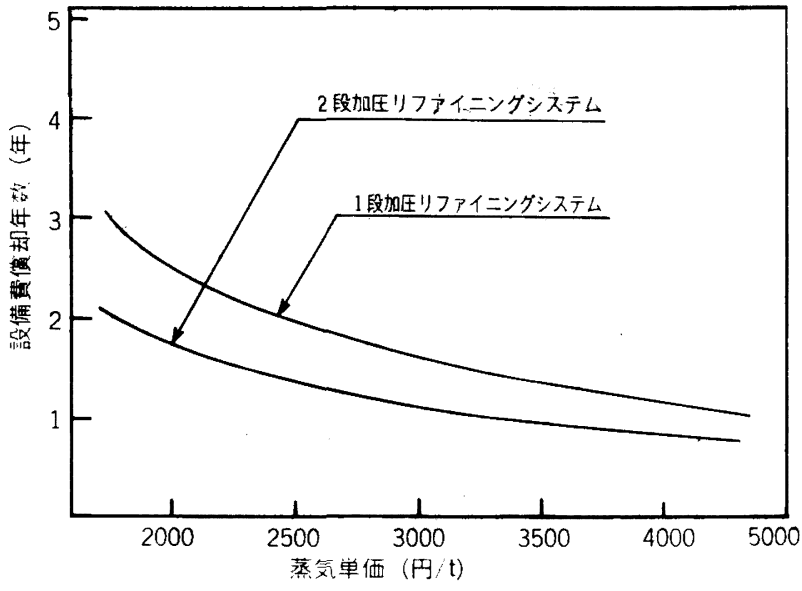

図 9 エパポレーター式熱回収装置の蒸気単洒と設備費償却年数

年以下で設備費が債却できることになり， 設備投資するだけの価値が十分あると言 える。

廃熱回収装置の経済性は, 一般にクリ ーン蒸気量で置き換わるプロセス蒸気量 などに対して，製紙会社独自の電力単価 と蒸気単価とから設備費償却期間を算出 し評価する例が多い。しかし，電力単価 と蒸気単価は自家発電と買電との比率, 昼間と夜間の買電単価の違いを考㦄した 操業比率などにより大きく変るので，奏 情に合わて評価していく必要がある。

\section{4. あとがき}

ここに TMP プラントの省エネ対策の 一つとして，廃蒸気からクリーン蒸気を 発生させる方法を述べてきた。この方法

ここで，設備費には大気王りフォイニングシステム から加圧リフォイニングシステムへの変換に必要な改 造費にクリーン蒸気発生用機器・配管・電気・計装設 備一式および据付工事を含んでいる。運転維持費は電 力代およびメンテナンス費などを含んでいる。

図9より，1段加王リフォイニングシステムの場合 2 年で，2段加圷りフォイニングシステムの場合 1.5 によるエネルギー回収の効果は大きく，TMP プロセ スの省エネを考える上での参考になれば幸いである。 しかし，クリーン蒸気は工場内での用途によりその価 值が判断され，すへててのケースで有効とは言えない。 TMP プラントはリファイナー動力が生命であり，パ ルプ品質を損なわずに低減されて初めて真の省エネ対 策となることを付記しておく。 